\title{
KEDUDUKAN SERTIFIKASI HALAL DALAM SISTEM HUKUM NASIONAL SEBAGAI UPAYA PERLINDUNGAN KONSUMEN DALAM HUKUM ISLAM
}

\author{
Panji Adam Agus Putra \\ Universitas Islam Bandung Jl. Ranggagading No. 08 Bandung Jawa Barat Indonesia
}

Panjiadam06@gmail.com

\begin{abstract}
Abstrak
Tujuan penelitian ini untuk mengetahui kedudukan sertifikasi halal dalam sistem hukum nasional dan sistem tertulis fatwa MUI sebagai upaya perlindungan konsumen dalam hukum Islam, dengan menggunakan metode pendekatan Yuridis normatif. Sertifikasi halal adalah pengakuan kehalalan suatu produk yang dikeluarkan oleh BPJPH berdasarkan fatwa tertulis yang dikeluarkan oleh Majelis Ulama Indonesia. Pengesahan UUJPH menimbulkan prokontra dari berbagai pihak. Kedudukan sertifikasi halal dalam sistem hukum Nasional di Indonesia mempunyai kedudukan yang sentral karena sudah menjadi regulasi dalam peraturan perundang-undangan di Indonesia khsusunya Undang-Undang Nomor 33 Tahun 2014 tentang Jaminan Produk Halal. Selain itu, Fatwa halal yang dihasilkan oleh MUI ditaati dan dipatuhi oleh pemerintah dan umat Islam. Pemerintah mematuhinya seperti tercermin dalam peraturan perundang-undangan yang ada.
\end{abstract}

Kata Kunci: Sertifikasi Halal, Perlindungan Konsumen, Hukum Islam

\section{Abstract}

The purpose of this study was to determine the position of halal certification in the national legal system and the MUI written fatwa system as an effort to protect consumers in Islamic law, using normatif yuridical approuch methods. Halal certification is a recognition of halal products issued by BPJPH bases written advice that issued by Indonesian Council of Ulama. UUJPH validation evokes pro con of a variety party. Halal product assurance in National jurisdictional system at Indonesia has to domicile that central because have become regulation in legislation regulation at Indonesian especially Number Law 33 Years 2014 about Halal product assurance. Besides, Resulting kosher advice by MUI is abode by and obeyed by government and Islam people. Government obeys as most regulation deep mirror aught legislation.

Keyword: halal certification, consumer protection, Islamic law

Received: 2017-01-17| Reviced: 2017-01-25 | Accepted: 2017-01-31

Indexed : DOAJ, Garuda, Crossref, Google Scholar | DOI: https://doi.org/10.29313/amwaluna.v1i1.2172 


\section{PENDAHULUAN}

\section{A. Latar Belakang Masalah}

Makanan adalah segala sesuatu yang berasal dari sumber hayati dan air, baik yang diolah maupun tidak diolah, yang diperuntukan sebagai makanan atau minuman bagi konsumsi manusia, termasuk bahan tambahan pangan, bakan baku pangan, dan bahan lain yang digunakan dalam proses penyiapan, pengolahan, dan/atau pembuatan makanan dan minuman (Zulham, 2013)

Makanan halal adalah pangan yang tidak mengandung unsur atau bahan yang haram atau dilarang untuk dikonsumsi umat Islam, baik yang menyangkut bahan baku pangan, bahan tambahan pangan, bahan bantu dan bahan penolong lainnya termasuk bahan pangan yang dioleh melalui proses rekayasa genetika dan iradia pangan, dan yang pengelolaannya dilakukan sesuai dengan ketentuan hukum agama Islam (Pasal 1 angka 5 PP No. 69 Tahun 1999 tentang Label dan Iklan).

\section{K.H Ma'ruf Amin (Amin,} 2013)menyatakan bahwa makanan halalharam bukan hanya masalah umat muslim saja, melainkan juga berkaitan dengan masyarakat luas pada umumnya. Karena itu, agar ibadah dan doa diterima oleh Allah, maka harus berusaha semaksimal mungkin agra makanan dan minuman yang dikonsumsi terjamin halâl dan thayyib-nya, sebagai bagian dari syarat diterimanya ibadah dan doa. Jaih Mubarok (Mubarok, 2006) mengemukakan bahwa membicarakan halal-haram lebih banyak berhubungan dengan makanan, minuman, dan pakaian. Oleh sebab itu, menggunakan atau mengkonsumsi produk halal menurut keyakinan agama (Islam) dan/atau demi kualitas hidup dan kehidupan, merupakan hak warga negara yang dijamin oleh Undang-Undang Dasar 1945 (Mashudi, 2015)

Kata halâl berasal dari bahasa Arab yang berarti "melepaskan" dan "tidak terikat", secara etimolgis halâl berarti halhal yang boleh dan dapat dilakukan karena bebas atau tidak terikat dengan ketentuanketentuan yang melarangnya. (Ma'luf, 1986) Atau diartikan segala sesuatu yang bebas dari bahaya duniaw dan ukhrawi. Sedangkan tayyib berarti makanan yang tidak kotor atau rusak dari segi zatnya atau tercampur benda najis dengan pengertian baik. Ada juga yang mengartikan sebagai makanan yang mengundang selera konsumennya dan tidak membahayakan fisik serta akalnya, yang secara luas dapat diartikan dengan makanan yang menyehatkan.

Masalah halâl dan harâm dalam Islam mempunyai kedudukan yang sangat penting, sebab masalah tersebut meliputi hampir sebagian besar ajaram Islam. Pada 
garis besarnya ajaran Islam itu terbagi ke dalam 3 (tiga) kelompok, yaitu pertama, berisi perintah-perintah (al-awâmir) yang harus dikerjakan oleh umat Islam baik sebagai hamba Allah maupun sebagai khalifah-Nya di muka bumi (khalîfah Allâh fî al-ardh). Kedua, berisi larangan-larangan (al-nawâhî) yang harus ditinggalkan oleh umat Islam. Ketiga, pentunjuk-petunjuk (al-irsyâdât) untuk kebahagiaan hidup manusia di duna dan akhirat. (Muhammadiyah) Dari kelompok pertama, lahirlah ajaran-ajaran yang harus ditaati, sedangkan dari kelompok kedua alhirlah ajaran-ajaran yang harus dijauhi dan dihindari.

Ketiga pokok bahasan tersebut kemudian diperinci lagi ke dalam beberapa bagian. Pokok pembahasan pertama, misalnya diperinci menjadi empat bagian, yaitu makanan dan minuman (al-ath'imah wa al-asyribah), pakaian dan perhiasan (almalbas wa al-zînah), rumah tempat tinggal (al-maskan), dan pekerjaan (al-kasb wa alihtiraf). Pada semua bagian tersebut, Islam telah menetapkan batasan yang tegas antara halal dan haram seperti tercermin dalam hadis yang diriwayatkan oleh Imam alBukhari dari Nu'man bin Basyir r.a (alBukhar)

Selanjutnya Islam memberikan penjelasan mengenai persoalan-persoalan mana saja yang halal dan mana saja yang haram. Dalam masalah makanan, misalnya, pada dasarnya Islam menghalalkan semua jenis makanan dan minuman yang baik dan bergizi (al-thayyibât) dan mengharamkan semua jenis makanan dan minuman yang menjijikan (al-khabâ'its) (Q.S 7: 157). Ketentuan tersebut kemudian diperinci lagi oleh Allah dalam surat al-Baqarah ayat 173.

Ayat tersebut menjelaskan secara tegas mengenai 4 (empat) jenis makanan yang haram dikonsumsi yaitu bangkai, darah, babi, dan binatang yang disembelih untuk selain Allah. Sementara itu, hanya ada 1 (satu) jenis minuman yang diharamkan, yaitu khamar sperti dijelaskan oleh Allah Swt dalam surat al-Maidah ayat 90. Di luar itu, hadis-hadis Nabi Saw menambahkan beberapa jenis binatang yang haram dikonsumsi seperti biantang buasa yang bertaring, berkuku tajamm, binatanh yang hidup di dua alam (darat dan laut), potongan dari binatang yang masih hidup, dan sebagainya. (Sabiq, 1983)

Sementara itu dalam "Panduan Sertifikat Halal" yang dikeluarkan oleh Departemen Agama, dijelaskan bahwa produk yang halal adalah produk yang memenuhi syarat kehalalan sesuai dengan syariat Islam, antara lain (RI, 2008):

1. Tidak mengandung babi dan bahan yang berasal dari babi; 
2. Tidak mengandung bahan-bahan yang diharamkan seperti bahan-bahan yang berasal dari organ mansia, darah, dan kotoran;

3. Semua bahan yang bersal dari hewan yang disembelih menurut tata cara syariat Islam;

4. Semua tempat penyimpanan, tempat penjualan, tempat pengolahan, tempat pengelolaan dan transportasi tidak boleh digunakan untuk babi dan/atau barang tidak halal lainnya. Jika pernah digunakan untuk babi dan/atau barang tidak halal lainnya terdahulu harus dibersihkan dengan tata cara syariat Islam; dan

5. Semua makanan dan minuman yang tidak mengandung khamar.

Maka, secara umum makanan dan minuman yang haram terdiri dari binatang, tumbuh-tumbuhan sebagai berikut:

1. Bianatang: bangkai, darah, babi, dan hewasn yang disembelih dengan nama selain Allah (Q.S 2: 173). Hewan yang dihalalkan akan berubah statusnya menjadi haram apabila mati karena tercekik, terbentur, jatuh tertanduk, diterkam binatang buas dan yang disembelih untuk berhala (Q.S 5: 3), kecuali ikan dan belalang boleh dikonsumsi tanpa disembelih. Binatang yang dipandang jijijk atau kotor menurut naluri manusia (Q.S 7: 157)
(Imam al-Ghazali, 2002: 119). Binatang dan burung buas yang bertaring dan memiliki cakar, binatang-bianatang yang oleh ajaran Islam diperintahkan membunuhnya seperti ular, gagak, tikus, anjing galak, dan burung elang dan sejenisnya, binatang-binatang yang dilarang membunuhnya seperti semut, lebah, burung hudhud, belatuk, hewan yang hidup di dua jenis alam seperti kodok, penyu dan buaya.

2. Tumbuh-tumbuhan, sayur-sayuran, dan buah-buahan boleh dimakan kecuali yang mendatangkan baya atau memabukan baik secara langsung maupun melalui proses. Maka semua jenis tumbuh-tumbuhan yang mengandung racun atau yang memabukan haram dimakan.

3. Semua jenis minuman adalah halal kecuali minuman yang memabukan seperti arak dan yang dicampur dnegan benda-benda najis, baik sedikit maupun banyak.

Pengaturan penggunaan produk halal di Indonesia, memiliki 2 (dua) hal yang saling terkait, yaitu sertifikasi dan lebelisasi. Sertifikasi halal adalah fatwa tertulis MUI yang menyatakan kehalalan suatu produk sesuai syariat Islam melalui pemeriksaan yang terperinci oleh LPPOM MUI. Sertifikasi halal imi merupakan 
syarat untuk mendapatkan izin pencantuman label halal pada kemasan produk dari instansi pemerintah yang berwenang (Badan POM).

Adapun labelisasi halal adalah perizinan pemasangan kata "Halal" pada kemasan produk dari suatu perusahaan oleh Bandan POM. Izin pencantuman label halal pada kemasan produk makanan yang dikeluarkan oleh Badan POM didasarkan rekomendasi MUI dalam bentuk sertifikat halal MUI. Sertifikat halal MUI dikeluarkan oleh MUI berdasarkan hasil pemeriksanaan LP POM MUI.

Menurut Mashudi (Mashudi, 2015) Pemerintah telah merespon secara positif pentingnya sertifikasi dan pencantuman tanda atau tulisan halal pada produk (labelisasi halal) melalui beberapa regulasi. Akan tetapi, regulasi ini masih terkesan sektoral dan parsial. Padahal, pangan sebagai kebutuhan dasar manusia yang pemenuhannya merupakan hak asasi setiap rakyat Indonesia harus senantiasa tersedia cukup setiap waktu, aman, bermutu, bergizi, dan beragam dengan harga yang terjangkau oleh daya beli masyarakat (Departemen Agama, 2003: 310), perlu mendapat perlindungan hukum dan jaminan kepastian hukum kehalalan untuk dikonsumsi, terutama umat Islam yang wajib dilindungi dan diberi hak menjalankan ibadah seusai dengan manat
UUD 1945 terutama Pasal 28 dan 29 (Hazairin, 1990).

Dalam upaya menjamin perlindungan dan kepastian hukum produk pangan halal, perlu diselenggarakan suatu penyelenggaraan pangan yang dilakukan untuk memenuhi kebutuhan dasar manusia yang memberikan manfaat secara adil, merata, dan berkelanjutan dengan berdasarkan pada Kedaulatan, Pangan, Kemandirian Pangan, dan Ketahanan Pangan. Pada 16 November 2012 telah disahkan oleh Presiden Republik Indonesia Undang-Undang Republik Indonesia Nomor 18 Tahun 2012 tentang Pangan (selanjutnya disingkat UUPangan).

Sebelum lahir UUPangan, disadari perlu adanya upaya pemberdayaan konsumen melalui pembentukan undangundang yang dapat me,indungi kepentingan konsumen secara integratif dan komprehensif serta dapat diterapkan secara efektif di masyarakat, maka diundangkanlah Undang-Undang Republik Indonesia, yaitu Undang-Undang Nomor 8 Tahun 1999 tentang Perlindungan Konsumen (UUPK). UUPK ini dirumuskan dengan mengacu pada filosofi pembangunan nasional bahwa pembangunan nasional termausk pembangunan hukum yang memelihara perlindungan terhadap konsumen dalam rangka membangun manusia Indonesia 
seutuhnya yang berlandaskan pada falsafah kenegaraan Republik Indonesia, yaitu dasar negara Pancasila dan konstitusi negara Undang-Undang Dasar 1945.

UUPK pada dasarnya bukan merupakan awal dan akhir dari hukum yang mengatur tentang perlindungan konsumen. Selanjutnya ditegaskan dalam penjelasan umum UUPK bahwa di kemudian hari masih terbuka kemungkinan terbentuknya undang-undang baru yang pada dasarnya memuat ketentuan-ketentuan yang melindungi konsumen. Dengan demikian, UUPK ini merupakan payung yang mengintegrasikan dan memperkuat penegakan hukum di bidang perlindungan konsumen.

Sertifkat halal sebagai perlindungan konsumen dari berbagai macam makanan yang dianggap tidak layak sesuai syariat Islam khususnya Indonesia yang pendudukan mayoritas beragama Islam, juga memberikan keuntungan mendorong kompetensi dan menjadi keunggulan pasar. Sertifikat halal saat ini menjadi salah satu poin untuk daya saing di perdagangan internasional. Pencantuman label halal juga bermanfaat untuk melindungi barang hasil produksi dalam negeri dari serbuan produk asing karena adanya perdagangan bebas (free trade).

Sebagaimana uraian di atas, pemerintah telah merespon secara positif pentingnya sertifikasi halal dan pencantuman label/tanda halal pada produk (labelisasi halal) melalui beberapa regulasi. Akan tetapi, regulasi ini masih saja terkesan sektoral dan parsial. Kesan itu, misalnya terlihat ketika mencermati Undang-Undang RI Nomor 19 Tahun 2012 tentang Pangan, Undang-Undang RI Nomor 8 Tahun 1999 tentang Perlindungan Konsumen Pasal 8 ayat (1) huruf h, Peraturan Pemrintah RI Nomor 69 Tahun 1999 tentang Label dan Iklan Pangan, Instruksi Presiden RI Nomor 2 Tahun 1991 tentang Peningkatan Pembinaan dan Pengawasan Produksi dan Peredaran Makanan Olahan, Piagam Kerjasama Departemen Kesehatan, Departemen Agama dan MUI tentang Pelaksanaan Pencantuman Label "Halal" pada makanan, dan Kseimpulan Mudzakarah Nasional tentang Alkohol dalam Produk Makanan (Hakim, 1432 H/2011 M)

Oleh sebab pentingnya sertifikasi halal guana melindungi kepentingan konsumen, sertifikasi halal perlu mendapatkan kedudukan dan posisi serta mendapatkan payung hukum agar masuk ke dalam sebuah sistem hukum khususnya sistem hukum nasional.

\section{B. Rumusan Masalah}

Berdasarkan urian pada latar belakang di atas, maka permasalahan tersebut dirinci menjadi dua permasalahan 
sebagai berikut: (1)Bagaimana kedudukan sertifikasi halal dalam sistem hukum nasional sebagai upaya perlindungan konsumen dalam hukum Islam? (2) aimana kedudukan sertifkasi halal sebagai fatwa tertulis Majelis Ulama Indonesia sebagai upaya perlindungan konsumen dalam hukum Islam?

\section{Tujuan Penulisan}

Berdasarkan perumusan masalah di atas, maka tujuan penulisan ini adalah sebagai berikut: (1)Untuk mengetahui kedudukan sertifikasi halal dalam sistem hukum nasional sebagai upaya perlindungan konsumen dalam hukum Islam. (2) Untuk mengetahui kudukan sertifkasi halal sebagai fatwa tertulis Majelis Ulama Indonesia sebagai upaya perlindungan konsumen dalam hukum Islam.

\section{Kerangka Pemikiran}

Sistem hukum (legal system) menurut bahasa adalah satu kesatuan hukum yang tersusun dari tiga unsur, yaitu:

$$
\text { (1) struktur; (2) substansi; }
$$

kultur/budaya hukum (Friendman). Dengan demikian, jika berbicara tentang "sistem hukum”, ketiga unusr tersebut yang menjadi fokus pembahasannya. Struktur adalah keseluruhan institusi penegakan hukum, beserta aparatnya yang mencakup kepolisian dengan para polisinya, kejaksaan dengan para jaksanya, kantor-kantor pengacara dengan para pengacaranya, dan pengadilan dengan para hakimnya. Substansi adalah keseluruhan asas hukum, norma hukum, dan aturan hukum, baik tertulis maupun tidak tertulis, termasuk putusan pengadilan. Kultur hukum adalah kebiasaan, opini, cara berpikir dan cara bertindak, dari para penegak hukum dari warga masyarakat.

Dalam menganalisis perkembangan sistem hukum dalam penegakan hukum, sebagian pihak menawarkan reformasi sistem hukum. Akan tetapi, permasalahannya adalah, apakah yang dibutuhkan itu reformasi sistem hukum ataukah penggantian sistem hukum secara total? Reformasi sistem hukum adalah perubahan yang akan terjadi pada struktur, substansi, atau kultur hukum.

Seiring dengan proses reformasi dewasa ini, bangsa Indonesia tengah dihadapkan pada suatu realita bahwa sistem hukum nasional tidak berlaku efektif di tengah masyarakat karena proses penegakan hukum yang lemah dan kurang tumbuhnya kesadaran hukum nasional di tengah masyarakat. Sistem hukum nasional yang seharusnya dapat berfungsi sebagai pedoman berperilaku dalam masyarakat sepertinya menghadapi kenyataan bahwa selalu ada kesenjangan antara substansi hukum positif yang dirumuskan (rule of law) dan apa yang dipikirkan dan apa yang 
dilakukan oleh masyarakat (social behaviour). (Praja, 2011)

Teori maslahah mursalah pertama kali diperkenalkan oleh Imam Malik (W. $97 \mathrm{H}$ ), pendiri mazhab Maliki. Namun, karena pengikutnya yang lebih akhir mengingkari hal tersebut, maka setelah abad ketiga hijriyah tidak ada lagi ushûl alfiqh yang menisbatkan maslahah mursalah kepada Imam Malik (Hallag, 2000), sehingga tidak berlebihan jika ada pendapat yang menyatakan bahwa teori maslahah mursalah ditemukan dan dipopulerkan oleh ulama-ulama ushûl al-fiqh dari kalangan Syafi'iyah, yaitu Imam al-Haramain alJuwaini (W. 478 H), guru Imam al-Ghazali. Dan menurut beberapa hasil penelitian, ahli ushûl al-fiqh yang paling banyak membahas dan mengkaji maslahah mursalah adalah Imam al-Ghazali yang dikenal dengan sebutan hujjat al-Islâm.

Secara etimologis, kata mashlahah berasal dari bahasa Arab: al-mashlahah dan telah dibakukan ke dalam bahasa Indonesia menjadi kata maslahah, selanjutnya juga digunakan kata maslahah saja yang berarti manfaat atau sesuatu pekerjaan yang mengandung manfaat. Atau sesuatu mendatangkan kebaikan atau membawa kemanfaatan dan/atau menolak kerusakan (Farih, 2008)

Menurut bahasa asilinya, kata mashlahah al-mursalah berasal dari kata saluha, yashulu, salahan, yang artinya sesuatu yang baik, patut, dan bermanfaat. Sedangkan kata mursalah artinya terlepas bebas, tidak terikat dengan dalil agama (alQur'an dan al-Hadits) yang membolehkan atau melarangnya (2008: 15).

Sedangman menurut etimologis, maslahah diartikan oleh para ulama dengan rumusan hampir bersamaan, di antaranya al-Khawarizmi (w. 977 H) menyebutkan, maslahah adalah memelihara tujuan hukum Islam dengan menolak bencana/kerusakan/hal-hal yang merugikan diri sendiri. sedangkan ulama telah berkonsensus, bahwa tujuan hukum Islam adalah untuk memelihara agama, akal, jiwa, keturunan dan harta.

Urgensi kemaslahatan atau maslahah mursalah terdapat pada semua bentuk hukum, baik hukum-hukum yang berdasarkan wahyu seperti hukum Islam maupun hukum yang bukan berdasarkan wahyu, walupun penekanan dari masingmasing hukum tersebut berbeda. Perbedaan itu berkaitan dengan hukum Islam dan merupakan keistimewaan hukum Islam itu sendiri. perbedaan dan keistimewaan hukum Islam itu adalah (Asafri Jaya Bakri, 1996: 142-143): (a) pengaruh kemaslahatan hukum Islam itu tidak terbatas waktu di dunia, tetapi juga memberi pengaruh pada kehidupan akhirat. Hal ini disebabkan, syariat Islam itu sendiri diciptakan untuk 
kebahagiaan dunia dan kahirat; (b) kemaslahatan yang dikandung oleh hukum Islam, tidak saja berdimensi materi (mâdi) akan tetapi juga immateri (rûhi) terhadap manusia; dan (c) dalam hukum Islam, kemaslahatan agama merupakan dasar bagi kemaslahatan-kemaslahatan yang lain. Hal ini mengandung arti bahwa pabila terjadi pertentangan antara kemaslahatan yang lain dengan kemaslahatan agama, maka kemaslahatan agama tidak boleh dikalahkan atau dikorbankan.

Melalui teori maslahah mursalah ini akan terlihat apakah UUPK, UUJPH dan UUPanngan yang telah diberlakukan sudah memformulasikan jaminan perlindungan dan kepatian hukum produk halal bagi konsumen muslim di Indonesia atau belum. Untuk itu, penulis akan melakukan kajian (bagaimana) sesungguhnya reformulasi pengaturan yang ideal tentang sertifasi halal sebagai bentuk jaminan perlindungan dan kepatian hukum produk pangan halal bagi konsumen muslim di Indonesia. Karena menurut Hazairin (Hazairin, 1990), bahwa negara Republik Indonesia berewajiban membentuk sistem hukum nasional Indonesia yang sumber hukumnya adalah hukum agama.

\section{E. Metode Penelitian}

\section{Pendekatan Penelitian}

Penelitian ini menggunakan pendekatan yuridis normatif, yaitu dengan mengkaji atau menganalisis data sekunder yang berupa bahan-bahan hukum sekunder dengan memahami hukum sebagai perangkat peraturan atau norma positif di dalam perundang - undangan yang berlaku, jadi penelitian ini dipahami sebagai penelitian kepustakaan, yaitu penelitian terhadap bahan sekunder (Soekanto \& Mamudji, 1985)

Alasan penelitian ini menggunakan pendekatan yuridis normatif adalah karena penelitian ini menggunakan data sekunder yang bertujuan untuk menganalisis data sekunder berupa perundang-undangan yang sesuai dengan fokus penelitian ini.

Disamping itu penelitian ini menggunakan pendekatan comparative atau perbandingan, yaitu untuk menemukan persamaan dan perbedaan antara berbagai konsep atau pendepat mengenai perlindungan konsumen menurut hukum positif dan hukum Islam.

\section{Sifat Penelitian}

Sifat penelitian ini adalah penelitian deskriptif analitis, yaitu penelitian untuk menggambarkan masalah yang ada pada masa sekarang (masalah yang aktual), dengan mengumpulkan data, menyusun, mengklasifikasikan, menganalisis, dan 
menginterpretasikan. Deskriptif bertujuan memaparkan data hasil pengamatan tanpa pengujian hipotesis-hipotesis. (Adi, 2004)

\section{Jenis Data}

Oleh karena penelitian ini tergolong penelitian yuridis normatif, maka data yang diperlukan adalah data sekunder. Adapun data primer dalam penelitian ini berupa wawancara hanya sebagai penguat dan tambahan saja. Data sekunder yang diperlukan adalah bahan hukum primer yang bersumber dari sumber primer, yaitu undang-undang yang relevan dengan rumusan masalah. Selain bahan hukum primer juga diperlukan bahan hukum sekunder yang bersumber dari data sekunder, yaitu buku-buku atau kitab-kitab (fikih, hadis, syarah hadis dan tafsir) literatur sertifikasi halal fatwa MUI dan tulisan-tulisan hukum lainnya yang relevan dengan rumusan masalah. Diperlukan juga bahan hukum tersier, seperti kamus dan ensiklopedia baik hukum maupun umum yang berbahasa Arab, Inggris dan Indonesia.

\section{Teknik Pengumpulan Data}

Berdasarkan jenis data yang akan dipergunakan dalam penelitian ini, yaitu data sekunder yang bersifat kualitatif, maka teknik pengumpulan data yang akan ditempuh adalah dengan cara studi kepustakaan. Studi kepustakaan ini dapat diartikan sebagai suatu kegiatan (praktis dan teoritis) untuk mengumpulkan (inventarisasi), dan mempelajari (teaching and learning), serta memahami (reflektif, kritis dan sistematis serta logis) data yang berupa hasil pengolahan orang lain, dalam bentuk teks otoratif (peraturan perundangundangan, putusan hakim, traktat, kontrak, keputusan Tata Usaha Negara, kebijakan publik, dan lainnya), literatur atau buku teks, jurnal, artikel, arsip atau dokumen, kamus, ensiklopedi dan lainnya yang bersifat publik dan privat.

Untuk memperoleh data yang diperlukan dalam penelitian ini digunakan alat dan cara sebagai berikut:

a. Studi Kepustakaan

Dalam hal mempelajari bahanbahan yang merupakan data sekunder, pertama mempelajari peratiran perundang-undangan yang menjadi objek penelitian, dipilih dan dihimpun kemudian dari bahanbahan itu dipilih asas dan kaidah hukum mengenai sertifikasi halal. Setelah itu dipilih kerangkan yang sistematis untuk memudahkan analisisnya.

b. Wawancara

Wawancara ini ditunjukan kepada narasumber dengan pertimbangan dapat memperkuat data dokumen yang berkaitan dengan masalah dalam penelitian ini. Narasumber di 
sini adalah Majels Ulama Indonesia (MUI) Jawa Barat. Bentuk wawancara yang digunakan adalah wawancara berpedoman, yaitu materi pertanyaan yang telah dipersiapkan terlebih dahulu sebelum melakukan wawancara. Wawancara ini hanya sekedar sebagai bahan pendukung atau tambahan saja.

\section{Teknis Analisis Data}

Teknis analisis data yang digunakan dalam penelitian ini adalah metode kualitatif normatif. Analisis terhadap data sekunder yang bersifat kualitatif tersebut dilakukan dengan cara berlandaskan pada teori hukum ataupun doktrin hukum yang terdapat pada kerangka pikir, kemudian diterapkan secara deduktif terhadap identifikasi masalah dari penelitian tesis ini, yang selanjutnya akan ditarik suatu kesimpulan yang bisa menjawab permasalahan-permasalahan yang menjadi masalah dalam penulisan ini.

\section{PEMBAHASAN}

Sistem hukum Indonesia sebagai sebuah sistem aturan yang berlaku di negara Indonesia adalah sistem aturan sedemikian rumit dan luas, yang terdiri dari unsur-unsur hukum, dimana di antara unsur hukum yang satu dengan yang lain saling bertautan, saling mempengaruhi serta saling mengisi. Oleh karenanya membicarakan satu bidang atau unsur atau subsistem hukum yang berlaku di Indonesia tidak bisa dipisahkan dari yang lain, sehingga mirip dengan tubuh manusia, unsur hukum bagaikan satu organ yang keberadaannya tidak bisa dipisahkan dari organ yang lain. (Bisri, 2012)

Istilah sistem berasal dari perkataan systema dalam bahasa Latin, Yunani yang artinya keseluruhan yang terdiri bermacammacam bagian. Secara umum sistem didefinisikan sekumpulan elemen-elemen yang saling berinteraksi untuk mencapai suatu tujuan tertentu di dalang lingkungan yang kompleks. (Is, 2015)

Undang-undang Nomor 33 Tahun 2014 tentang Jaminan Produk Halal (atau diseingkat UUJPH) disahkan oleh Dewan Perwakilan Rakyat tepat pada tanggal 25 September 2014. Undang-Undang ini diharapkan dapat memberikan solusi bagi masyarakat dan dunia usaha dalam rangka perlindungan terhadap konsumen dan sekaligus menjadi payujng hukum berbagai macam jenis produk halal pada produk makanan, minuman, obat, kosmetik, produk kimia, produk biologi, dab produk rekayasa genetik. Pemerintah yang dimotori oleh Departemen Agama dan berbagai lembaga masyarakat mendukung sepenuhnya penerapan UUJPH ini. Dengan diberlakukannya UUJPH ini diharapkan produk-produk Indonesia dapat bersaing 
serta mutu dan kualitas dengan produk asing dan dapat diminati oleh konsumen terutama konsumen yang beragama Islam baik konsumen lokal maupun asing.

Ada tiga kekuatan berlakunya UUJPH, yaitu: pertama, kekuatan berlaku yuridis (juristische geltung). Undangundang mempunyai kekuatan berlaku yuridis apabila persyaratan formal terbentuknya undang-undang itu telah terpenuhi (Sudikno Mertekusumo, t.th: 72). Menurut Hans Kelsen (Kelsen, 1995) kaidah hukum mempunyai kekuatan berlaku apabila penetapannya didasarkan atas kaidah yang lebih tinggi tingkatannya. Suatu kaidah hukum merupakan sistem kaidah secara hierarchies. Di dalam grundnorm (norma dasar) terdapat dasar berlakunya semua kaidah yang berasal dari satu tata hukum. Dari grundnorm itu hanya dapat dijabarkan berlakunya kaidah hukum dan bukan isinya. Pembahasan mengenai berlakunya hukum berhubungan dengan das sollen, sedangkan das sein berhubungan dengan pengertian hukum. Ketentuan hukumnya berdiri kukuh di antara dua kaki, yakni ranah das sein dan das sollen.

Kedua, kekuatan berlaku swosiologis (soziologische geltung). Berlakunya atau diterimanya hukum di dalam masyarakat sama sekati tidak terkait dari kenyataan apakah peraturan hukum itu terbentuk menurut persyaratan formal atau tidak. Sehingga yang ditekankan dalam hal ini adalah kenyataan di dalam masyarakat. kekuatan berlakunya hukum dalam masyarakat ini ada 2 (dua) macam: (1) menurut teori kekuatan (nachtstheorie), hukum mempunyai kekuatan berlaku sosiologis apabila dipaksakan berlakunya oleh penguasam terlepas dari diterima ataupun tidak oleh warga masyarakat; (2) menurut teori pengakuan (anerkennungstheorie) hukum mempunyai kekuatan berlaku sosiologis apabila diterima dan diakui warga masyarakat.

Ketiga, kekuatan berlaku secara filosofis (fiosofische geltung). Hukum mempunyai kekutan berlaku filosofis apabila kaidah hukum tersebut sesuai dengan cita hukum (rechtsidee) (Sumardi, 2009) sebagai nilai positif yang tertinggi. Menurut Stammler, cita hukum berfunsgi sebagai "bintang pemadu" (leitstern) bagi terciptanya cita-cita masyarakat. Meskipun merupakan "titik akhir" yang tidak mungkin dicapai, cita huum bermanfaat karena pada satu sisi ia dapat menguji hukum yang berlaku, dan pada sisi lain dapat mengarahkan hukum positif yang mengatur tata kehidupan masyarakat dengan sanksi pemaksa menjadi sesuatu yang adil. Cita hukum tidak hanya berfungsi sebagai tolak ukur bersifat regulatis yang menguji apakah suatu 
hukum positif adil atau tidak adil, tetapi sekaligus berfungsi sebagai dasar konstitutif yang menentukan bahwa tanpa cita hukum maka hukuk kehilangan maknanya sebagai hukum.

Berkaitan dengan sertifikasi halal ini, maka ilosofis pranata hukum yang mendasarinya adalah: a) Dominan agama adalah al-Qur'an dan al-Hadits; b) sedangkan pada dominan hukum positif didasarkan pada Undang-Undang Nomor 36 Tahun 2009 tentang Kesehatan, Undang-Undang Nomor 18 Tahun 2012 tentang Pangan, Undang-Undang Nomor 8 Tahun 1999 tentang Perlindungan Konsumen dan terakhir Undang-Undang Nomor 33 Tahun 2014 tentang Jaminan Produk Halal.

Oleh karena itu, dapat disimpulkan bahwa kedudukan sertifikasi halal dalam sistem hukum Nasional di Indonesia mempunyai kedudukan yang sentral, karena sertifikasi halal termaktub dalam Undang-Undang Nomor 33 Tahun 2014 tentang Jaminan Produk Halal yang secara sistem hukum merupakan bagian dari sistem hukum, yaitu substansi hukum yang mempunyai kekuatan hukum dan kepastian hukum serata bersifat imperatif. Dan hal ini sebagai upaya perlindungan konsumen dalam hukum Islam.

Fatwa adalah pertimbangan hukum Islam yang dikeluarkan oleh mufti atau ulama, baik secara individu maupun kolektif sebagai jawaban atas pertanyaan yang diajukan atau respons terhadap masalah yang berkembang di tengah-tengah masyarakat. Sekalipun kerap dianggap tidak mempunyai kekuatan hukum mengikat (ghair mulzimah), fatwa mempunyai peranan yang cukup signifikan dalam memberikan pertimbangan hukum keagamaan kepada masyarakat muslim dari dahulu hingga sekarang. Dalam konteks masyarakat Indonesia, fatwa-fatwa yang dilahirkan oleh lembaga keagamaan, termasuk Majelis Ulama Indonesia (MUI) mempunyai pengaruh yang tidak kecil. (Sholeh, 2016)

Kedudukan fatwa halal Majelis Ulama Indonesia (MUI) pada dasarnya sama seperti fatwa ulama pada umumnya, yaitu terkait dengan lembaga yang menghasilkan fatwa tersebut, yaitu ulama yang tergabung MUI khususnya dalam Komisi Fatwa MUI. Dalam Islam, kedudukan ulama terkait dengan keistimewaan yang mereka miliki di antaranya sebagai ahli waris para nabi (warâtsah al-anbiyâ) sebagaimana dinyatakan dalam hadis Nabi Saw berikut ini:

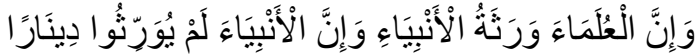

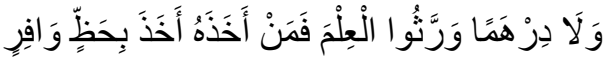

Para ulama adalah pewaris para nabi, dan para nabi tidak mewariskan dinar dan dirham, mereka hanyalah 
mewariskan ilmu. Barangsiapa mengambilnya maka ia telah mengambil bagian yang banyak (H.R Abub Daud).

Berdasarkan uraian di atas, maka fatwa halal yang dihasilkan oleh MUI ditaati dan dipatuhi oleh pemerintah dan umat Islam. Pemerintah mematuhinya seperti tercermin dalam peraturan perundang-undangan yang ada. Wahiduddin Adams dalam disertasinya menyimpulkan bahwa sejumlah fatwa MUI dapat diserap dalam peraturan perundangundangan negara kita dengan beberapa pola.

Ketaatan pemerintah terhadap fatwa halal MUI terlihat dalam peraturan perundang-undangan yang berlaku dan kebijakan-kebijakan yang dibuat pemerintah berkaitan dengan persoalan kehalalan pangan. Hal ini tercermin dalam Undang-Undang Nomor 36 Tahun 2009 tentang Kesehatan, Undang-Undang Nomor 18 Tahun 2012 tentang Pangan, UndangUndang Nomor 8 Tahun 1999 tentang Perlindungan Konsumen dan terakhir Undang-Undang Nomor 33 Tahun 2014 tentang Jaminan Produk Halal.

Selanjutnya, dalam Peraturan Pemerintah Nomor 9 Tahun 1999 tentang "Label dan Iklan Pangan" Pasal 11 ayat (2) disebutkan, "Pemeriksaan sebagaimana dimaksud pada ayat (1) dilaksanakan berdasarkan pedoman dan tata cara yang ditetapkan oleh Menteri Agama dengan memperhatikan pertimbangan dan saran lembaga keagamaan yang memiliki kompetensi di bidang tersebut". Dalam penjelasannya disebutkan bahwa lembaga keagamaan dimaksud adalah Majelis Ulama Indonesia (MUI). Dengan demikian, MUI diakui sebagai lembaga keagamaan yang berkompeten dalam memutuskan kehalalan pangan. Maka, fatwanya yang berkaitan dengan hal tersebut, yaitu Fatwa Halal diakui dan menjadi rujukan pemerintah. (Sopa, 2013)

Selanjutnya, dalam Pasal 11 dan 12 ditegaskan bahwa lebilisasi halal itu hanya dapat dilakukan beradasarkan "Sertifikasi Halal" yang dikeluarkan oleh MUI. Hal ini terlihat dari kedua pasal tersebut. Dalam Pasal 11 ditegaskan bahwa persteujuan pencantuman tulisan "Halal" diberikan berdasarkan Fatwa dari Komisi Majelis Ulama Indonesia. Kemudian dalam Pasal 12 ayat (1) disebutkan bahwa beradasarkan "Fatwa dari Majelis Ulama Indonesia Direktur Jenderal memberikan persetujuan bagi yang memperoleh sertifikat "HALAL" dan penolakan bagi yang tidak memperoleh sertifikat "HALAL".

Fatwa Halal juga dipatuhi oleh produsen pangan. Pihak produsen umumnya menanggapi positif keberadaan sertifikasi halal tersebut. Darwies Ibramim, 
direktur pengembangan usaha PT Indofood Sukses Makmur, memberikan penlaian pentingnya Sertifikat Halal karena bagi perusahaannya sertifikat itu mempunyai arti yang strategis lantara mayoritas konsumen produknya adalah umat Islam. Oleh karena itu, pihaknya sudah mengusulkan adanya Sertifikat Halal itu kepada Departemen Agama dan Departemen Kesehatan pasca isu lemak babi tang terjadi pada tahun 1988 (Republika, 26 Juli 1996).

Sertfikat Halal juga dipatuhi oleh konsumen yang mayoritas beragama Islam. Hal ini terlihat jelas dalam kasus lemak babi 1988 dan Ajinomoto tahu 2000. Dalam kedua kasus tersebut, jelas terlihat peran ulama dalam menentramkan umat melalui fatwa yang dikeluarkannya. Dengan demikian, tidak berlebihan apabila dikatakan bahwa Majelis Ulama Indonesia (MUI) telah memainkan perannya sebagai pemberi fatwa kepada umat Islam dan pemerintah, baik diminta maupun tidak diminta sebagaimana disebutkan dalam Wawasan Majelis Ulama Indonesia dan Pedoman Dasar MUI (Pasal 4) meskipun pada hakikatnya fatwa ulama itu tidak mengikat sebagaimana keputusan Pengadilan Agama dan Undang-Undang.

\section{Simpulan}

Berdasarkan uraian dan analisis pada bab sebalumnya, maka di bawah ini dapat ditarik beberapa kesimpulan sebagai berikut:

Kedudukan sertifikasi halal dalam sistem hukum Nasional di Indonesia mempunyai kedudukan yang sentral, karena sertifikasi halal termaktub dalam Undang-Undang Nomor 33 Tahun 2014 tentang Jaminan Produk Halal yang secara sistem hukum merupakan bagian dari sistem hukum, yaitu substansi hukum yang mempunyai kekuatan hukum dan kepastian hukum serata bersifat imperatif. Dan hal ini sebagai upaya perlindungan konsumen dalam hukum Islam.

Fatwa halal yang dihasilkan oleh MUI ditaati dan dipatuhi oleh pemerintah dan umat Islam. Pemerintah mematuhinya seperti tercermin dalam peraturan perundang-undangan yang ada. Ketaatan pemerintah terhadap fatwa halal MUI terlihat dalam peraturan perundangundangan yang berlaku dan kebijakankebijakan yang dibuat pemerintah berkaitan dengan persoalan kehalalan pangan. Hal ini tercermin dalam Undang-Undang Nomor 36 Tahun 2009 tentang Kesehatan, Undang-Undang Nomor 18 Tahun 2012 tentang Pangan, Undang-Undang Nomor 8 Tahun 1999 tentang Perlindungan Konsumen dan terakhir Undang-Undang Nomor 33 Tahun 2014 tentang Jaminan Produk Halal.

DAFTAR PUSTAKA 
Panji Adam Agus Putra, Kedudukan Sertifikasi Halal Dalam Sistem Hukum Nasional

Adi, R. (2004). Metode penelitian Sosial dan Hukum. Jakarta: Granit.

al-Bukhar, M. I.-M. (n.d.). Shahîh alBukhârî. Kairo: Dar al Hadits.

Amin, M. (2013). "Halal Berlaku Untuk Seluruh Umat”. Jurnal Halal Nomor. 1. Th. XVI, LPPOM MUI.

Bisri, I. (2012). Sistem Hukum Indonesia: Prinsip-prinsip \& implementasi Hukum di Indonesia. Jakarta: Raja Grapindo Persada.

Farih, A. (2008). Kemaslahatan \& Pembaharuan Hukum Islam. Semarang: Walisongo Press.

Friendman, L. M. (n.d.). The Legal System: a Social Science Prerspective. New York: Russell.

Hakim, L. (1432 H/2011 M, jumadil SaniRajab). Sayang Ya Sertifikasi halal Masih Urusan Sukarela. majalah Aulia No 12 Tahun VIII.

Hallag, W. B. (2000). A History of Islamic Legal Theories, Alih Bahasa E. Kusnadiningrat . Jakarta: rajawali Press.

Hazairin. (1990). Demokrasi pancasila. Jakarta: Rineka Cipta.
Is, M. S. (2015). Pengantar Ilmu Hukum . Jakarta: Kencana.

Kelsen, H. (1995). General Theory of Law And State, Alihbahasa Somardi. Jakarta: ramdi Press.

Ma'luf, L. (1986). al-Munjid Lughah wa alA'lam. Beirut: Dar al Masyariq.

Mashudi. (2015). Konstruksi Hukum dan Respons Masyarakat Terhadap Sertifikasi Halal: Studi Socio-Legal Terhadap Lembaga Pengkajian Pangan, Obat-Obatan, Dan Kosmetika Majelis Ulama Indonesia. Yogyakarta: Pustaka Pelajar.

Mubarok, J. (2006). Hukum Islam: Konsep, Pembaruan dan Teori Penegakan. bandung: Benang Merah.

Muhammadiyah, P. P. (n.d.). Himpunan Putusan Majlis Tarjih Muhammadiyah.

Praja, J. S. (2011). Teori Hukum dan Aplikasinya. Bandung: Pustaka Setia.

RI, D. A. (2008). Panduan Sertifikat Halal. Jakarta: Direktorat Jenderal Bimbingan.

Sabiq, S. (1983). Fiqh al Sunat. Beirut: Dar al Fikr. 
Sholeh, M. A. (2016). Metodologi

Penetapan Fatwa Majelis Ulama

Indonesia: Penggunaan Prinsip

Pencegahan dalam Fatwa. Jakarta:

Emir Cakrawala.

Soekanto, S., \& Mamudji, S. (1985).

Penelitian Hukum Normatif (Suatu

Tinjauan Singkat) . Jakarta: rajawali

Pers.

Sopa. (2013). Sertifikasi Halal Majelis

Ulama Indonesia: Studi Atas Fatwa

Halal MUI Terhadap Produk

Makanan, Obat-Obatan dan

Kosmetika . Jakarta: Gaung Persada

Press Group (GP Press).

Sumardi, A. (2009). Porf. Mr. Soediman

Kartohadiprodjo tentang Pancasila

Sebagai Pandangan Hidup Bangsa

Indonesia. Jakarta.

Zulham. (2013). Hukum Perlindungan

Konsumen. Jakarta: Kencana

Prenada Media Group. 